\section{EREM 76/1}

Journal of Environmental Research, Engineering and Management

Vol. 76 / No. 1 / 2020

pp. 20-31

DOI 10.5755/j01.erem.76.1.22212
Electro-biosystems with Mosses on Green Roofs

Received 2018/12

Accepted after revision 2020/02

\title{
Electro-biosystems with Mosses on Green Roofs
}

\section{Iryna Rusyn*}

Lviv Polytechnic National University, Institute of Sustainable Development

Department of Ecology and Sustainable Nature, Bandera Street 12, Lviv, 79013, Ukraine

\section{Khrystyna Hamkalo}

Lviv Polytechnic National University, Institute of Sustainable Development

Department of Ecology and Sustainable Nature, Bandera Street 12, Lviv, 79013, Ukraine

\section{*Corresponding author: rib7@i.ua}

The article presents the research of bioelectricity generation by electro-biosystems with mosses in containers with soil substrate and a graphite-Zn-steel system of electrodes on green roofs during the autumn-winter-spring period. The experiment was carried out on the roof of the educational building of Lviv Polytechnic University, Ukraine. It was revealed that the optimum conditions for the functioning of electro-biosystems were the temperature above $+10^{\circ} \mathrm{C}$ with simultaneous regular humidification of the soil. In these conditions, an average current of $19.50 \mathrm{~mA}$ was recorded. Electro-biosystems reacted by lowering in the level of the produced bioelectric potential and current at a temperature drop below $10^{\circ} \mathrm{C}$, particularly in frost, and also in the long absence of atmospheric precipitation. The electrode system configuration had an important value for their functionality. Electro-biosystems with a few single graphites as cathodes, connected by conductors into a single cathode system to varying degrees survived the winter period; in some of them, connections between the electrodes were damaged due to the effect of frozen water. The most optimal configuration of an electrode system for generating bioelectricity was the system consisting of one monolithic graphite cathode, located in the depth of the soil under rhizoids and vertically located anodes. This electro-biosystem was stable and operated at the initial level after the winter period. Thermo-insulated electro-biosystems with frost-resistant mosses under the conditions of regular humidification are the basis for further development and improvement of biotechnology in terms of maximising the obtained bioelectricity and have prospects of being used for low-energy consumption needs on green roofs of buildings.

Keywords: microbial-plant bioelectricity, green roofs, electro-biosystems, electrode systems, renewable energy.

\section{Introduction}

The technology of arrangement of green roofs, both on the roofs of private buildings and on urban high-rises, has become very popular recently as one of the new approaches of architecture and urbanisation that emerges from the concepts of sustainable urban development (Kohler, 2005; Fotouchi, 2015; Konyuhov et al., 2019). The quantity of green roofs is increasing rapidly every year worldwide. The total area of green 
roofs in Japan increased about 29-fold between 2000 and 2013 years (Kuronuma et al., 2018). As part of the carbon-neutral city strategy to 2025, Copenhagen, Denmark, has become the first Scandinavian city to adopt a policy that requires green roofs for all new buildings with roof slopes of less than 30 degrees (Chino, 2010). From 2016, in Cordoba, Argentina, all new and existing rooftops with an area of over $400 \mathrm{~m}^{2}$ have to be turned into green roofs. In Connecticut, the green roof industry has increased by 35\% every year since 2007 (Lubell et al., 2013).

Green roofs add the necessary additional green space to paved cities covered with asphalt, reducing atmospheric pollution, preserving species biodiversity and positively affecting the climate of urban ecosystems (Getter \& Rowe, 2006; Yang et al., 2008). Green roofs in cities are an important tool in dealing with the effects of global climate change, reducing urban heat island temperatures (Banting et al., 2005; Alexandri \& Jones, 2006) and reducing greenhouse gas concentrations (Clark et al., 2005; Dimitrijevic et al., 2018; Kuronuma et al., 2018), solving the problem of rainwater runoff, reducing the risk of flooding (Mentens \& Hermy, 2006; Konasova, 2014), insulating buildings from winter cold and summer heat (Theodosiou, 2003; Konyuhov et al., 2019), thereby reducing $\mathrm{CO}_{2}$-dependent energy costs for heating and air-conditioning (Oberndorfer et al., 2009; Castleton et al., 2010). In addition, green roofs are promising in terms of receiving bioelectricity (Helder et al., 2013a). The essence of obtaining bioelectricity from green roofs is that soil electrical-generating microorganisms produce bioelectricity, utilising organic matter released into the substrate through the root system by actively photosynthetic plants (De Schamphelair et al., 2008; Kaku et al., 2008; Strik et al., 2008) or in the process of decay of organic fall of plant foliage (Timmers et al., 2012; Dai et al., 2015).

Most works with bioelectric microbial-plant systems is carried out in swampy and synthetic substrates (Helder et al., 2010; Timmers et al., 2012; Yadav et al., 2012; Liu et al., 2013) with higher plants, mainly by wetland residents (Lu et al., 2015; Oon et al., 2015; Wetser et al., 2015; Rusyn \& Hamkalo, 2018). Requirements for plants of extensive green roofs are stress tolerance: endurance under limited acreage for root development and low nutrient reserves, resistance to intense solar radiation and wind, dry and frost resistance (Getter \& Rowe, 2006; Oberndorfer et al., 2009; Konasova, 2014). The low-growing species of succulents of the genus Sedum are the most researched and widely used plants for extensive green roofs (Monterusso et al., 2005; Rowe et al., 2005; Tapia et al., 2017). Mosses have high prospects as candidates for extensive green roofs (Studlar \& Peck, 2009; Konasova, 2014) because of their stress-resistance and unpretentious ability to form a green roof carpet (Cooper, 1975; Atherton et al., 2010; Buck \& Goffinet, 2000) and ability to generate bioelectricity (Bombelli et al., 2016). Therefore, as a component of electro-biosystems for green roofs, we have chosen widespread species of moss, the electro-productivity of which has been poorly studied, and soil as a substrate for their development.

The technology of microbial-plant bioelectricity requires improvement due to the low productivity and freezing of plants in the winter on the rooftops (Helder et al., 2013b; Wetser et al., 2017). Whereas mosses are frost-resistant plants, using them as a biocomponent of green-roof electro-biosystems could solve this problem. In this article, we set ourselves the tasks to study out: 1) the possibility and perspective of using moss as a biocomponent of electro-biosystems (EBS) with graphite and galvanised-steel electrode systems, developed by us (Rusyn \& Medvediev, 2018) in soil substrate on green roofs; 2 ) to investigate generation of bioelectricity during the autumn-winter-spring period, at frosts and arid periods; and 3) to evaluate the role of the configuration of electrode systems for bioelectricity production.

\section{Methods}

\section{Set up of the experiment}

The experiment was carried out on the roof of the educational building of the Lviv Polytechnic University in the order of approaching the conditions of the green

roof. In contradistinction to green roofs, the construction consisted of separate containers with plants and electrodes without thermal insulation. For this 
purpose, 20 containers of $0.0525 \mathrm{~m}^{2}$ each were used, in which plants were planted and electrode systems were installed for collecting bioelectricity. The moss tracks of Hypnum cupressiforme Hedw., Polytrichum commune Hedw. and the green cushions of Leucobryum glaucum Hedw. brought from the forest were placed in containers on the substrate contained within the electrode systems. The medium for plant development consisted of a universal soil substrate Ecoflora. Different configurations of electrode systems were analysed in order to select the most effective ones. Also, the influence of meteorological conditions on the productivity of bioelectricity during the autumn-winter-spring period was studied.

\section{Installation of the electrical component of the biosystem}

The systems of electrodes constructed by us for collecting and measuring bioelectricity (Rusyn \& Medvediev, 2018) were located deep in plastic containers in the substrate in the zone of association of plant rhizoids and microorganisms, where the electrons and protons are released. The anodes were plates of galvanised steel of $292 \times 30 \times 0.8 \mathrm{~mm}$, and cathodes were graphite plates measuring $90 \times 30 \times 15 \mathrm{~mm}$ (Rusyn \& Medvediev, 2015). The electrodes were interconnected by copper multi-conductor wires with a cross section of $1.5 \mathrm{~mm}$ (Rusyn \& Medvediev, 2016).

The cathode system consisted of 8 graphites or one entire graphite plate (Fig. 1). In electro-biosystems 1-4, cathodes were connected with each other by a wire almost back to back forming one plate; in electro-biosystem 5, cathodes were connected by a conductor in such a way that the graphites were at a distance from each other, to increase the contact area of the cathodes with the soil. In electro-biosystem 6 , cathodes represented one graphite plate in the size of $220 \times 120 \times 15 \mathrm{~mm}$, connected to the wire. Cathode electrode systems were placed horizontally under plant rhizoids in electro-biosystems $1-4$ and 6 , and in electro-biosystem 5 , vertically under plant rhizoids.

The anode system consisted of 7 plates connected by wire and located in a container as follows:

in the form of the letter $L$ on one side of the cathodes and below them (EBS 1);

Fig. 1. Cathode and anode system allocation in EBS-containers: 1 - cathode, 2 - anode, 3 - output of the wire connecting the anode system, 4 - output of the wire connecting the cathode system, 5 - EBS container.

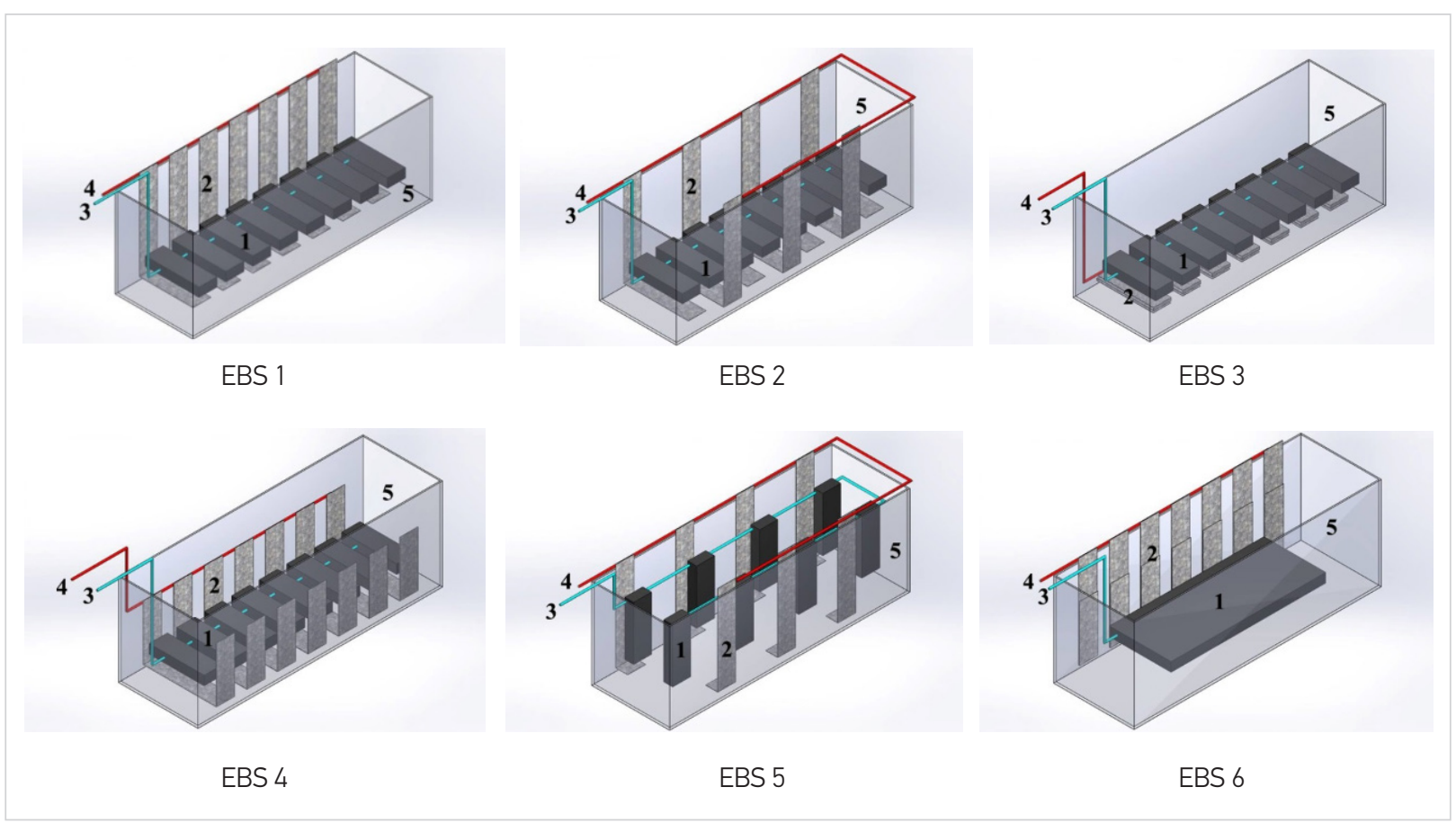


in the form of the letter $L$ on both sides of the cathodes alternately (EBS 2);

plates folded three times in the form of the letter I under the graphite system (EBS 3);

in the form of the letter $P$ under the cathodes and on both sides of graphites (EBS 4);

in the form of the letter $L$ on both sides of the cathodes (EBS 5);

twice-curved plates in the form of letter I on one side of the cathodes (EBS 6).

\section{Measurement and calculation}

Measures of current and bioelectric potential were performed daily using a digital multimeter. The values of the bioelectric potential and current were recorded by fixing the multimeter probes on the wires coming out of the soil and connecting the cathode and anode systems. Bioelectric potential was monitored in time over the process of the plant-microbial biosystem in an open circle. Experiments were conducted using different loads from 10 to $5000 \Omega$ to determine at which external resistance one can get the maximum power density. Resistors 10, 50, 250, 500, 1000, 3000, $5000 \Omega$ were used as external resistances. The voltage was recorded through the external resistor, periodically connected to the circle for 15 minutes. For analysis of short-term voltage, current and generation of electricity, polarisation measurements were made several times. The polarisation curves were obtained by changing the external resistance from $10 \Omega$ to $5 \mathrm{k} \Omega$. During experiments, the bioelectric potential was also measured when an external resistors $1 \mathrm{k} \Omega, 3 \mathrm{k} \Omega, 5 \mathrm{k} \Omega$ were permanently connected within a few days during few weeks. The current was calculated through practically measured voltage and resistance and was also measured by practically using resistors.

The current was calculated according to the formula (1):

$$
I(A)=\frac{U(V)}{R(\Omega)}
$$

and the current density was calculated in accordance with the formula (2):

$$
J\left(A / m^{2}\right)=\frac{l(A)}{S\left(m^{2}\right)}
$$

Where: $U$ - the measured voltage; $R$ - the external resistance; $S$ - the experimental area covered by the electrodes and plants.

Power density was calculated as

$$
P\left(W / m^{2}\right)=J\left(A / m^{2}\right) * U(V)
$$

Where: $J$ - the calculated current density; $U$ - the measured voltage.

The current density and power density were normalised to the $1-\mathrm{m}^{2}$ experimental planting area covered by the electrodes. The average bioelectric potential and current were calculated weekly. The calculation of average daily and average weekly ambient temperatures and the amount of rainfall was done by processing meteorological data from the rp5.ua meteorological station archive. The total rainfall per week and the daily rainfall were calculated weekly. The reported results were presented as the average of all replicate experiments and their standard errors (xSE). Significance of difference between average values was established using one-way analysis of variance and F-test for $95 \%$ confidence level.

\section{Results and Discussion}

\section{Bioelectricity of electro-biosystems with mosses on roofs during the autumn- winter-spring period. Effect of environment temperature on the generation of bioelectricity}

The whole complex of meteorological factors has a significant influence on the generation of bioelectricity by electro-biological systems in external conditions on roofs, in particular, the temperature of air, precipitation volume, amount of sunlight and related state of plants, viability of plants under conditions of sharp fluctuations of temperature and level of humidity. Meteo-conditions influence the intensity of plant photosynthesis, the development of plants and soil microorganisms, including electricity generative microorganisms. The influence of meteorological factors is more pronounced on the current. 
At the beginning of autumn, in conditions of average daily temperature above $+10^{\circ} \mathrm{C}$, the current in containers with mosses ranged from $16.28 \mathrm{~mA}$ to $22.71 \mathrm{~mA}$ and was kept at this level for almost the whole autumn. At the end of October, with the decrease in average daily temperature and regular night frosts, the current strength in all containers dropped to an average of $10.71 \mathrm{~mA}$ (Fig. 2). The late autumn and winter periods, from the end of November to the end of February, were characterised by periods of minus midweek temperatures from $-0.60^{\circ} \mathrm{C}$ to $-3.77^{\circ} \mathrm{C}$, alternating by periods of plus average weekly temperatures from $+1.85^{\circ} \mathrm{C}$ to $+4.41^{\circ} \mathrm{C}$. During the late-autumn-winter period, the current dropped even lower and kept low, an average of $3.52 \mathrm{~mA}$; at that time, bioelectricity was produced mainly due to the decomposition of plant fallout. During local periods of temperature rise, the current increased and decreased significantly during frosts compared with the initial values $(p<0.05)$ (Fig. 2). Thus, at the end of December, with a prolonged increase in the air temperature to the average weekly temperature of $+4.40 \mathrm{C}$, the average current rose to $11.39 \mathrm{~mA}$, but during long periods of minus temperatures in all winter months, was dropping to an average of $0.45-0.69 \mathrm{~mA}$. In the first two months of spring, the average daily temperature was still low, close to winter thaw temperatures, and averaged only $3.97^{\circ} \mathrm{C}$. At this time, the current rose slightly and averaged $6.04 \mathrm{~mA}$, which was only $31.37 \%$ of the average values of the beginning of autumn.

A pronounced rise in the values of the current began to be observed in May, when the average daily temperature rose above $+10^{\circ} \mathrm{C}$, an essential amount of precipitation fell, the number of sunny days increased and plant growth recovered. In May, in some electro-biosystems, the current strength increased to the original values that were at the beginning of autumn and amounted to an average of $17.70 \mathrm{~mA}(p>0.622)$ (Fig. 2). Other electro-biosystems after wintering did not restore the level of the current that was in them at the beginning of autumn, due to freezing of plants and damage of electrode connections under the pressure of frozen water. Non-acting electro-biosystems contained both non-viable plants and some plants that continued their development. In the first case, replacing frozen and dried mosses with new viable plants led to the restoration of current generation. However, in some cases, electro-biosystems needed repair of electrode systems. Replacing damaged connections of cathode systems in non-functioning electro-biosystems with active mosses without replacing the plant cover led to the restoration of their work and electrical performance at the initial level.

We found a suppressing effect of temperature below $10^{\circ} \mathrm{C}$ on the current of electrical biosystems with mosses, which often acted as a limiting factor and a suppressing effect of frosts, and the spring increase of the current with a temperature rise above $10^{\circ} \mathrm{C}$ and the development of plants. The criticality of temperature of $10^{\circ} \mathrm{C}$ for the functioning of electric biosystems is described by Hong et al. (2009) and Dai et al. (2015). Laboratory MFCs (Microbial fuel cell) were also least efficient at temperatures below $10^{\circ} \mathrm{C}$ (Li et al., 2013).

The general trends in the dynamics of bioelectric potential during seasonal temperature changes were similar to the correlation of current/temperature, but somewhat less pronounced in percentage terms. The bioelectric potential level exceeded $1 \mathrm{~V}$ and averaged $1032.67 \mathrm{mV}$ from September to mid-October, when the average weekly temperature ranged from $+10.16^{\circ} \mathrm{C}$ to $+16.09^{\circ} \mathrm{C}$ (Fig. 3). With a decrease in the average daily temperature below $+10^{\circ} \mathrm{C}$ and regular night frosts, a sharp decline in bioelectric potential below $1 \mathrm{~V}$ was observed from the end of October, which was maintained throughout the winter and the first two months of spring. A decrease in the level of bioelectric potential during frosts was statistically significant in comparison with the average initial value of September $(p<0.05)$. During the periods of thaw and plus temperatures in the winter, there was an increase in the level of bioelectric potential (Fig. 3). Two distinct increases in bioelectric potential of electrical systems in December and April to baseline levels compared with average winter values on the background of suboptimal temperatures are associated with a long period of precipitation $(p<0.05)$. From the beginning of May, with the rise of the average daily temperature above $+10^{\circ} \mathrm{C}$, the bioelectric potential of electro-bio-systems increased significantly $(p<0.05)$ and even exceeded the initial average values of autumn and in some cases reached $61.79 \%$ of the average initial value of autumn, which in the latter case was associated with freezing of plants and damage of unions of electrodes in some electro-biosystems. 
Fig. 2. Generation of current of electrical biosystems 1-6 with mosses from September to June during the fluctuations of average weekly temperatures (marked in dark blue columns) and rainfall amount (marked in blue) $(x \pm S E, n=20)$. The current level of electro-biosystem 6 significantly decreased during periods of sub-zero temperatures compared with the initial values * $(p<0.05)$ and increased in spring to almost the initial value ${ }^{* *}(p>0.622)$ with increasing temperature and increasing precipitation

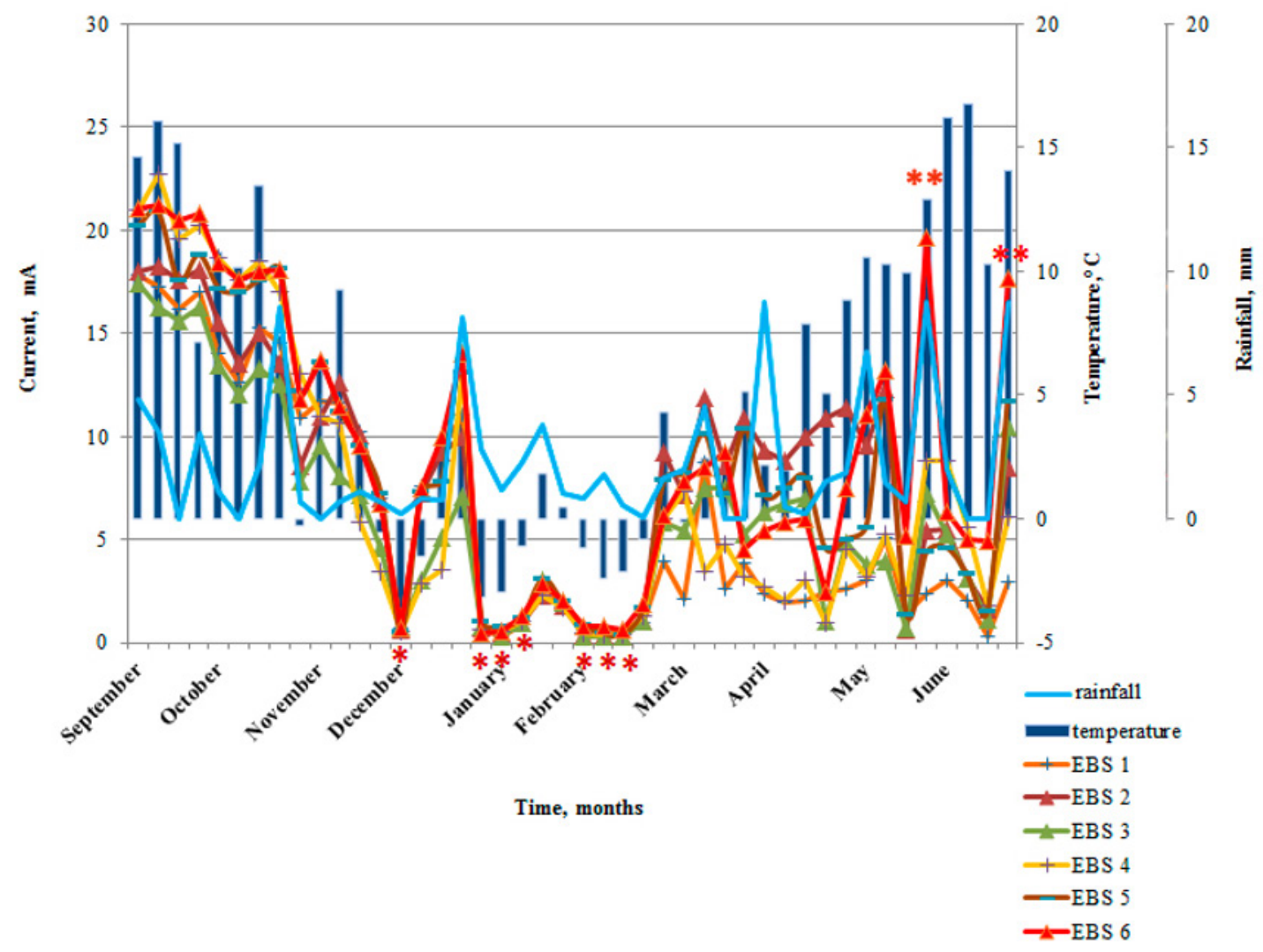

\section{Effect of atmospheric precipitation on the generation of bioelectricity by electro- biosystems with mosses on roofs during the autumn-winter-spring period}

The influence of the amount of atmospheric precipitation on the generation of bioelectric potential and current was revealed in combination with other meteorological factors. As in Dai et al. (2015), in the marshy electrical biosystems of Georgetown South Carolina, USA, a reduction of the current during long dry periods was recorded, and an increase of the current as a reaction to rainfall was found. Intense precipitates create favourable conditions for the development of electricity-generating microorganisms by dissolving and concentrating nutrients in the soil (Chow, 2006; Chow et al., 2013) and activating the photosynthesis of mosses themselves and secretion of their metabolic products.

The influence on the generation of bioelectricity of continuous rains and storms lasting several days one after another or a week and more was favourable at optimal temperatures. Particularly noticeable was the effect of extended multi-day precipitation; minor precipitation had a less pronounced effect on the generation of bioelectricity. For example, the 10-day period of rains from December 17 to December 27 during the rise of the average daily temperature, when 70.9 $\mathrm{mm}$ of precipitation fell during this period, led to an increase of the bioelectric potential of $167.83 \mathrm{mV}$ on average and a current of $3.88 \mathrm{~mA}(p<0.05)$ (Fig. 2, 3). Favourable high humidity with simultaneously 
unfavourable temperature factors and high cloudiness were accompanied by a decrease in bioelectric potential and current strength. In particular, the 10-day period of rains from March 27 to April 5, which was accompanied by periodic frosts, had no positive effect on the generation of bioelectricity and current (Fig. 2, 3).

Arid periods of up to 10-15 days periodically took place during the experiment. In the conditions of long absence of precipitation, the value of bioelectricity decreased, despite optimal temperatures. In particular, in May and June, despite the favourable temperature conditions, the current fluctuated sharply, which was closely related to arid periods and the sensitivity of mosses to moisture (Fig. 2). Mosses were stopping their activity during arid periods and restored activity and supported the development of electricity-generating microorganisms after rains. A similar dynamics was observed in the work of Dai et al. (2015), where during the arid period from July to December no bioelectricity was produced. Thus, due to an almost 20day dry period in June, during optimal temperatures, the local reduction of current strength was on average $76.67 \%$, and the bioelectric potential was $28.56 \%$ (Fig. 2, 3). Mosses are sensitive to the absence of rain and irrigation; during drought, they reduce their activity, stop the secretion of nutrients necessary for electricity-generating microorganisms, waiting for a favourable period. When restoring the moisture level

Fig. 3. Dynamics of generation of the average bioelectric potential of electro-biosystems 1-6 with mosses from September to June during fluctuations of average weekly temperatures (marked in dark blue columns) and rainfalls (marked in blue line) $(x \pm S E, n=20)$. The decrease in the level of bioelectric potential during frosts is statistically significant in comparison with the average initial value of September $(p<0.05)^{*}$. Two expressive peaks of increase in the values of bioelectric potential of electrical systems compared with average winter values to baseline levels in December and April are associated with a long period of precipitation in the context of temperature rise $(p<0.05)^{* *}$

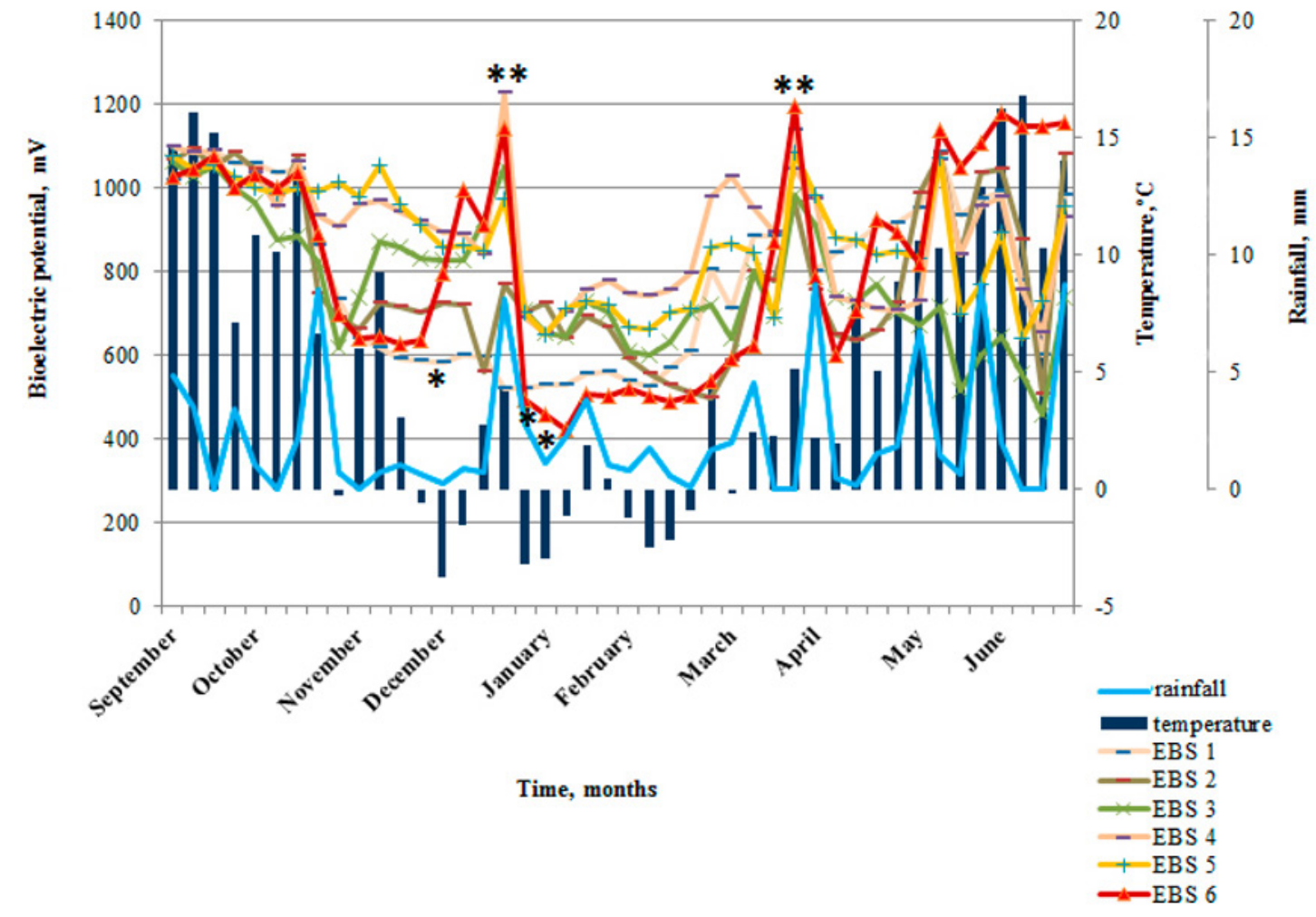


required for activity of mosses, the values of bioelectricity increase.

During the autumn-winter-spring period, containers with electro-biosystems on green roofs were in difficult weather conditions: sharp fluctuations in temperature, freezing up to $-19^{\circ} \mathrm{C}$ and thaws, prolonged droughts and showers. The share of electro-biosystems that successfully survived adverse weather conditions and came out after the winter period at the output values of bioelectric potential and restored the output values of the current was $16.71 \%$ of electro-biosystems. This is a rather good result obtained in the meteorological conditions of the Eastern European city of Lviv, Ukraine, given the fact that the species of plants of bioelectro-systems in the climatic conditions of the Danish winter on the roofs did not survive the winter (Helder et al., 2013b).

\section{Role of configuration of electrode system in the operation of electro-biosystems with mosses on green roofs during the autumn-winter period}

The most effective analysed configurationsof electrode systems (Fig. 1) was the system EBS6, consisting of a monolithic graphite cathode, located in the depths of the soil under rhizoids and vertically located anodes on one side. We constructed several configurations of electro-biosystems, where cathodes were represented by single graphites connected by conductors in a single system, and anodes were located both horizontally and vertically under the mosses rhizoids to increase the contact area of the electrodes with the ground and to reach a larger area of electron circulation. Theoretically, such a design allows more maximum to collect electrons produced by electric generating soil microorganisms. So, EBS4 and EBS5, where this strategy was most fully implemented, were characterised by significant higher values of current strength in the autumn period, before frosts, than electro-systems 1-3 $(p<0.05)$ (Fig. 2). However, such systems, with more connections, like EBS1-5, are technologically more vulnerable to the damaging effect of the expansion of frozen water, which damages contacts between electrodes, and often they are spoiled after the winter period. Although the EBS6 electrode surface area is somewhat smaller in comparison with EBS1-5, the functionality of the electro-biosystem with the configuration 6 during the experiment under the external conditions was stable, and the electrode system was not damaged; and in the spring, with the restoration of plant activity, the initial level of bioelectricity indicators was restored (Figs 2, 3).

Research of the work of bioelectrosystem 6 under short-term external load was carried out in the autumn period (Fig. 4). The resistors were briefly connected to electro-biosystems, starting from the largest, $12 \mathrm{k} \Omega$, successively to the lowest, $10 \Omega$. The bioelectric potential was lowered with a decrease in load, as described in Cheng et al. (2006), and the current density was increased. The highest values of the power density of $0.23-0.56 \mathrm{~W} / \mathrm{m}^{2}$ were fixed at 500-50 $\Omega$ (Fig. 4).

The level of the bioelectric potential of EBS6 during the long-term application, for several weeks, of the load of external resistances of 1,3 and $5 \mathrm{k} \Omega$ was analysed a few days after the polarisation measurements (Fig. 5). The application of the resistance of $1 \mathrm{k} \Omega$ led to a decrease in the values of bioelectric potential; subsequently, with the connection of the resistance of higher values of $3 \mathrm{k} \Omega$ and $5 \mathrm{k} \Omega$, the bioelectric potential increased (Fig. 5). Similarly, the growth of bioelectricity was recorded with an increasing load of external resistors in the work (Wetser et al., 2017). The low initial values of the bioelectric potential of the electro-biosystem 6 are due, obviously, to two factors, the overload of the electro-biosystem after a series of polarisation measurements with high resistances and the imposition of adverse meteos. The electro-biosystem 6 was resumed for several days. Within 10 days, when the resistance of $5 \mathrm{k} \Omega$ was connected, the electrical biosystem reached the level of the initial values without the use of resistances, and in the following days, the values of the bioelectric potential even increased (Fig. 5).

The cost of electrical systems for installing in an extensive container roof is $24.3-32.2 \mathrm{EUR} / \mathrm{m}^{2}$, depending on the type of cathodes used. The possibility to use graphite waste of trolleybus transport using graphite current collectors for trolleybus brushes makes technology cheaper. The developed model of electro-biosystems has prospects for use for low-energy consumption devices such as LED lighting and power supply of field sensors, and is the basis for further improvement of maximising the obtaining of bioelectricity. 
Fig. 4. Effect of short-term action of external resistance on bioelectric potential, power density and current density of electro-biosystem 6 with mosses during the autumn period, normalised to $1 \mathrm{~m} 2$ of the surface covered by plants and electrodes during the autumn period ( $x \pm S E, n=10)$. The maximum value of bioelectric potential and minimal value of current density of EBS6 was observed under of $12000 \Omega$ load
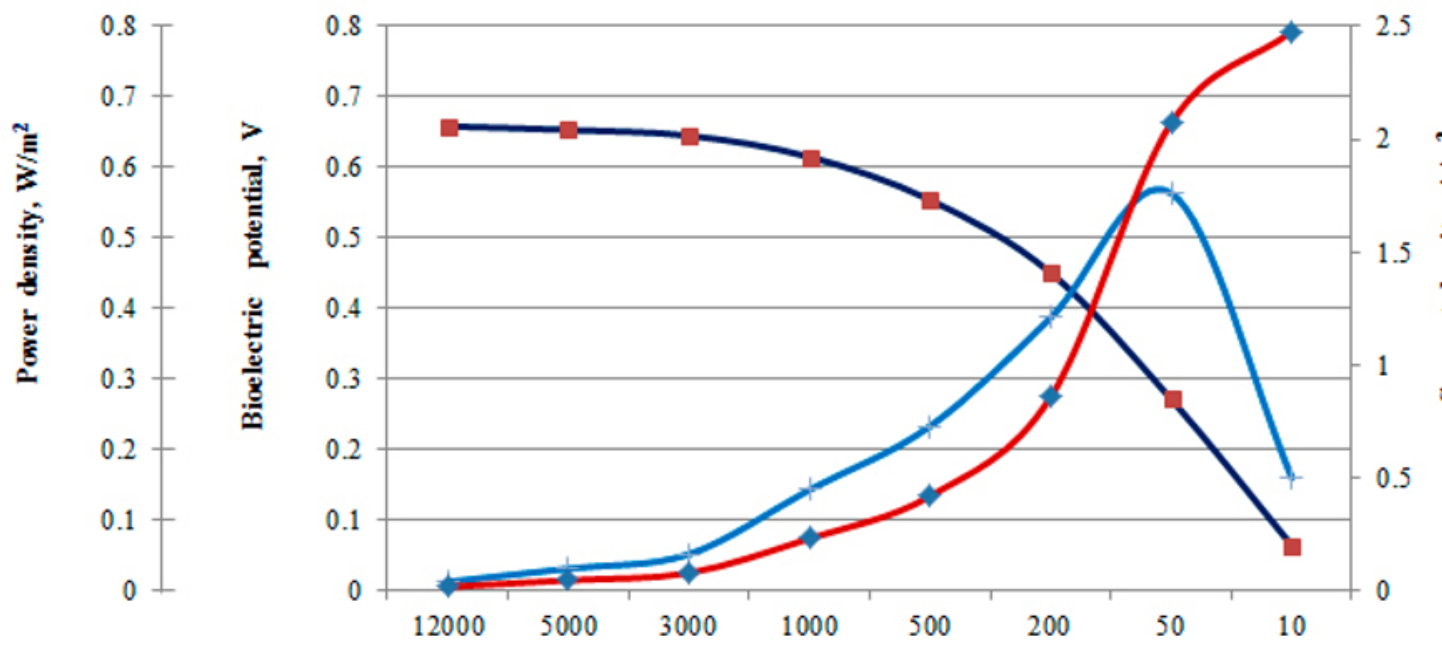

External resistance, $\Omega$

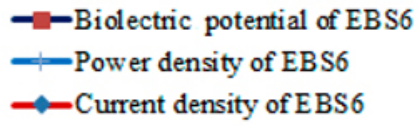

Fig. 5. Influence of external resistances on generation of the bioelectric potential by EBS6 during the autumn period on the roof of the building $(x \pm S E, n=10) .1 \mathrm{k} \Omega$ resistance was connected during 5-7 days, $3 \mathrm{k} \Omega$ for $8-10$ days and $5 \mathrm{k} \Omega$ for $11-26$ days

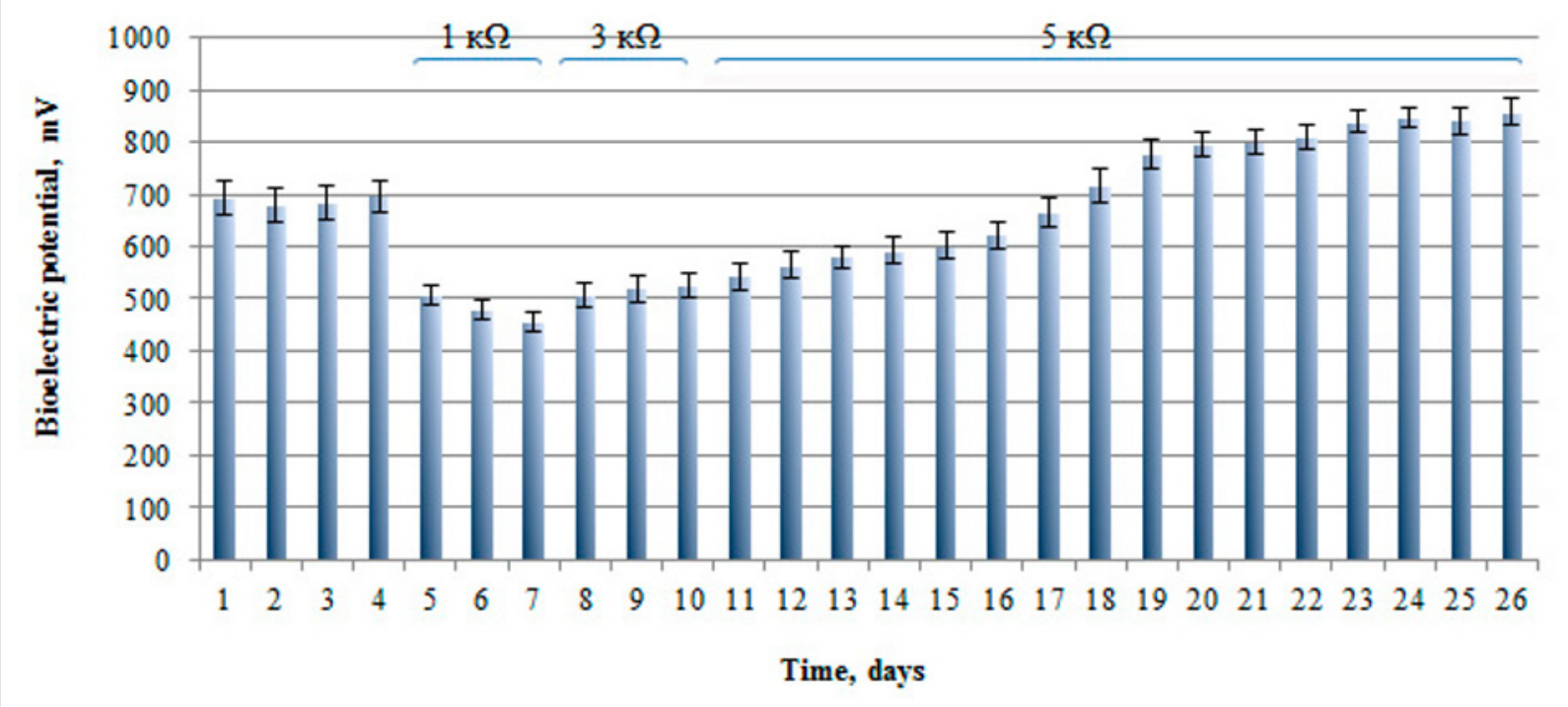




\section{Conclusions}

The possibility and perspective of using mosses as a biocomponent of electro-biosystems on green roofs in soil substrates with the graphite-Zn-steel systems of electrode were shown. The cathode system consisted of 8 single small graphites connected by wire or one entire large graphite plate, and the anode system consisted of 7 single connected Zn-steel plates. Ambient temperature and amount of rainfall collectively had a significant impact on the functioning of rooftop electrical biosystems and the generation of bioelectricity. Electro-biosystems operated at full capacity at temperatures above $+10^{\circ} \mathrm{C}$ and in the absence of prolonged droughts. The impact of long-term rainfall on the bioelectricity generation was favourable at optimum temperatures. Criticality of the temperature below $+10^{\circ} \mathrm{C}$ was found, which was often a limiting factor in the operation of electro-biosystems: favourable rainfall with a temperature below $+10^{\circ} \mathrm{C}$ was accompanied by a decrease in bioelectric potential and current. The suppressive limiting effect of frosts and prolonged droughts on the generation of bioelectricity by moss electro-biosystems was revealed. The configuration of the electrode systems was important for their efficiency. Electro-biosystems, where the configuration of the electrodes provided a larger area of contact with the substrate, allowed obtaining slightly higher values of bioelectricity, but technologically their contacts between electrodes were more susceptible to damage due to the expansion of frozen water, and they were more damaged after winter. Electro-biosystems with a monolithic graphite cathode proved to be most effective and at the same time resistant to weather damage. Electro-biosystems functioning at the initial level after wintering open the prospects for the use of electro-biosystems with frost-resistant mosses on green roofs of buildings after optimisation in the following areas: thermal insulation of containers, provision of regular moisturising and general raising of the level of bioelectric potential and current.

\section{Acknowledgements}

We express our great gratitude to Alexander Medvediev for analysis of data, consultations and graphic representation of 3D models of containers, as well as to Nazar Stempitskij, Bohdan Valko and Victoriya Vakulyuk for the technical assistance in the research and assembly of the electrode systems of collecting bioelectricity.

\section{References}

Alexandri E. \& Jones P. (2006) Temperature decreases in an urban canyon due to green walls and green roofs in diverse climates. Building \& Environment 48 (4): 480-493. https://doi. org/10.1016/j.buildenv.2006.10.055

Atherton I., Bosanquet S. \& Lawley M. (2010) Mosses and Liverworts of Britain and Ireland: a field guide. British Bryological Society, Plymouth.

Bombelli P., Dennis R.J., Felder F., Cooper M.B., Iyer D.M.R., Royles J., Harrison S.T, Smith A.G, Harrison C.J. \& Howe C.J. (2016) Electrical output of bryophyte microbial fuel cell systems is sufficient to power a radio or an environmental sensor. Royal Society Open Science 3 (10): 160249. doi: 10.1098/rsos.160249 https://doi.org/10.1098/rsos. 160249
Buck W.R. \& Goffinet B. (2000) Morphology and classification of mosses, 71-123. In: Shaw, A.J. \& Goffinet, B., Eds., Bryophyte Biology. Cambridge University Press, Cambridge. https://doi. org/10.1017/CB09781139171304.004

Castleton H.F., Stovin V., Beck S.B.M. \& Davison J.B. (2010) Green roofs; building energy savings and the potential for retrofit. Energy \& Buildings 42:1582-1591. https://doi.org/10.1016/j. enbuild.2010.05.004

Clark C., Talbot B., Bulkley J. \& Adriaens P. (2005) Optimization of green roofs for air pollution mitigation. In: Proceeding of 3rd North American Green Roof Conference: Greening rooftoops for sustainable communities, Washington, DC, The Cardinal Group, Toronto, 4-6 May 2005, pp 482-597. 
Chino M. (2010) Copenhagen Adopts a Mandatory Green Roof Policy. Available at: http://www.inhabitat.com/copenhagen-adopts-a-mandatory-green-roof-policy/ (accessed 6 September 2010).

ChowA.T.(2006)Disinfectionbyproductreactivity ofaquatichumic substances derived from soils. Water Research 40: 1426-1430. https://doi.org/10.1016/j.watres.2006.01.008

Chow A.T., Dai J., Conner W.H., Hitchcock D.R., \& Wang J.-J. (2013) Dissolved organic matter and nutrient dynamics of a coastal freshwater forested wetland in Winyah Bay, South Carolina. Biogeochemistry 112: 571-587. https://doi.org/10.1007/ s10533-012-9750-z

Cooper J. P. (1975). Photosynthesis and Productivity in Different Environments. International Biological Programme 3. Cambrige University Press, Cambrige and New York.

Dai J., Wang J.-J., Chow A.T. \& Conner W.H. (2015) Electrical energy production from forest detritus in a forested wetland using microbial fuel cells. Global Chance Biology Bioenergy 7: 244-252. https://doi.org/10.1111/gcbb.12117

DeSchamphelaire L., Van Den Bossche L., HaiS.D., Hofte M., Boon N., Rabaey K. \& Verstraete W. (2008) Microbial fuel cells generating electricity from rhizodeposits of rice plants. Environmental Science \& Technology 42(8): 3053-3058. doi: 10.1021/es071938w https://doi.org/10.1021/es071938w

Dimitrijevic D., Zivcovic P., Brancovic J., Dobrnjac M. \& Stefanovic Z. (2018) Air pollution removal and control by green living roof systems. Acta Technica Corviniensis - Bulletin of Engineering 11: 47-50.

Fotouchi F. (2015) The role of green roofs in sustainable development. Cumhuriyet University Faculty of Science Journal 36 (4): 414-420.

Getter K. L. \& Rowe D. B. (2006) The role of green roofs in sustainable development. HortScience 41: 1276-1286. https://doi. org/10.21273/HORTSCI.41.5.1276

Helder M., Strik D.P.B.T.B., Hamelers H.V.M., Kuhn A.J., Blok, C. \& Buisman, C.J.N. (2010) Concurrent bio-electricity and biomass production in three Plant-Microbial Fuel Cells using Spartina anglica, Arundinella anomala and Arundo donax. Bioresource Technology 101(10): 3541-3547. https://doi.org/10.1016/j. biortech.2009.12.124

Helder M., Chen W.S., Van Der Harst E.J.M., Strik D.P.B.T.B., Hamelers H.V.M., Buisman C.J.N. \& Potting J. (2013a) Electricity production with living plants on a green roof: environmental performance of the plant-microbial fuel cell. Biofuels Bioproducts \& Biorefining 7: 52-64. https://doi.org/10.1002/bbb.1373

Helder M., Strik D.P.B.T.B., Timmers R.A., Raes S.M.T, Hamelers H.V.M. \& Buisman C.J.N. (2013b) Resilience of roof-top
Plant-Microbial Fuel Cells during Dutch winter. Biomass \& Bioenergy 51: 1-7. https://doi.org/10.1016/j.biombioe.2012.10.011 Hong S.W., Chang I.S., Choi Y.S. \& Chung T.H. (2009) Experimental evaluation of influential factors for electricity harvesting from sediment using microbial fuel cell. Bioresource Technology 100 : 3029-3035. https://doi.org/10.1016/j.biortech.2009.01.030

Kaku N., Yonezawa N., Kodama Y. \& Watanabe K. (2008) Plant/ microbe cooperation for electricity generation in a rice paddy field. Applied Microbiology \& Biotechnology 79(1): 43-49. https://doi.org/10.1007/s00253-008-1410-9

Kohler M. (2005) The green roof movement - from a botanical idea to a new sustainable style in modern architecture. In: Proceedings of 1 th international landscape education symposium, Shanghai, China, pp168-176.

Konasova S. (2014) The role of green roofs in sustainable construction. In: Proceedings of Creative Construction Conference, Elsevier Procedia, Prague, Czech Republic, 21-24 June 2014, pp 470-478.

Konyuhov V.Yu., Gladkih A.M., Galyautdinov I.I., \& Kiseleva T.Yu. (2019) Ecological architecture: the green roofs. IOP Conference Series: Earth and Environmental Science 350: 012035. https:// doi.org/10.1088/1755-1315/350/1/012035

Kuronuma T., Watanabe H., Ishihara T., Kou D., Toushima K., Ando M., \& Shindo S. (2018) CO2 Payoff of Extensive Green Roofs with Different. Vegetation Species Sustainability 10 (2256): 1-12. https://doi.org/10.3390/su10072256

Li L.H., Sun Y.M., Yuan Z.H., Kong X.Y. \& Li Y. (2013) Effect of temperature change on power generation of microbial fuel cell. Environmental Technology 34 (13-16): 1929-1934. https://doi.org/10.1080/09593330.2013.828101

Liu S., Song H., Li X. \& Yang F. (2013) Power generation enhancement by utilizing plant photosynthate in microbial fuel cell coupled constructed wetland system. International Journal of Photoenergy, Article ID 172010: 1-10. https://doi. org/10.1155/2013/172010

Lubell J.D., Barker K.J. \& Elliott G.C. (2013) Comparison of Organic and Synthetic Fertilizers for Sedum Green Roof Maintenance. Journal of Environmental Horticulture 31(4): 227-233.

Lu L., Xing D. \& Ren Z.J. (2015) Microbial community structure accompanied with electricity production in a constructed wetland plant microbial fuel cell. Bioresource Technology 195: 115121. https://doi.org/10.1016/j.biortech.2015.05.098

Mentens D. R. \& Hermy M. (2006) Green roofs as a tool for solving the rainwater runoff problem in the urbanized 21 st century? Landscape \& Urban Planning 77: 217-226. https://doi. org/10.1016/j.landurbplan.2005.02.010

Monterusso M.A., Rowe D.B. \& Rugh C.L. (2005) Establishment and persistance of Sedum spp. and native taxa for green roof ap- 
plications. HortScience 40: 391-396. https://doi.org/10.21273/ HORTSCI.40.2.391

Oberndorfer E., Lundholm J., Brass B., Coffmann R., Doshi H., Dunnett N., Gaffin S., Köhler M., Liu K. \& Rowe B. (2007) Green roofs as urban ecosystems: ecological structures, functions, and services. Bioscience 57(10): 823-833. https://doi. org/10.1641/B571005

Oon Y.-L., Ong S.-A., Ho L.-N., Wong Y.-S., Oon Y.-S., Lehl H. K., \& Thung W.-E. (2015) Hybrid system up-flow constructed wetland integrated with microbial fuel cell for simultaneous wastewater treatment and electricity generation. Bioresource Technology 186: 270-275. https://doi.org/10.1016/j.biortech.2015.03.014

Rowe B., Monterusso M. \& Rugh C. (2005) Evaluation of Sedum species and Michigan native taxa for green roof applications. In: Proceeding of 3rd North American Green Roof Conference: Greening rooftoops for sustainable communities, Washington, DC, The Cardinal Group, Toronto, 4-6 May 2005, pp 469-481.

Rusyn I.B. \& Hamkalo Kh.R. (2018) Bioelectricity production in an indoor plant-microbial biotechnological system with Alisma plantago-aquatica. Acta Biologica Szegediensis 62 (2): 170-179. https://doi.org/10.14232/abs.2018.2.170-179

Rusyn I.B. \& Medvediev, O.V. (2018) Sposib otrymannia bioelektryky iz konteinera z roslynamy za dopomohoiu systemy elektrodiv [The method for bioelectricity obtaining from a container with plants using a system of electrodes]. Patent of Ukraine 122556, filed August 28, 2017, issued January 10, 2018 (in Ukrainian).

Strik D.P.B.T.B., Hamelers H.V.M., Snel J.F.H. \& Buisman C.J. (2008) Green electricity production with living plants and bacteria in a fuel cell. International Journal of Energy Research 32(9): 870-876. https://doi.org/10.1002/er.1397

Studlar S.M. \& Peck J.E. (2009) Extensive Green Roofs and Mosses: Reflections from a Pilot Study in Terra Alta, West
Virginia. Evansia 26 (2): 52-63. https://doi.org/10.1639/07479859-26.2.52

Tapia N.F., Rojas C., Bonilla C.A. \& Vargas I.T. (2017) Evaluation of Sedum as driver for plant microbial fuel cells in a semi-arid green roof ecosystem. Ecological Engineering 108(A): 203-210. https://doi.org/10.1016/j.ecoleng.2017.08.017

Theodosiou T.G. (2003) Summer period analysis of the performance of a planted roof as a passive cooling technique. Energy \& Buildings 35: 909-917. https://doi.org/10.1016/S03787788(03)00023-9

Timmers R.A., Rothballer M., Strik D.P.B.T.B., Engel M., Schulz S., Schloter M., Hartmann A., Hamelers B. \& Buisman C. (2012) Microbial community structure elucidates performance of Glyceria maxima plant microbial fuel cell. Applied Microbiology \& Biotechnology 94(2): 537-548. doi: 10.1007/s00253-012-3894-6 https://doi.org/10.1007/s00253-012-3894-6

Yadav A.K., Dash P., Mohanty A., Abbassi R. \& Mishra B. K. (2012) Performance assessment of innovative constructed wetland-microbial fuel cell for electricity production and dye removal. Ecological Engineering 47: 126-131. https://doi. org/10.1016/j.ecoleng.2012.06.029

Wetser K., Liu J., Buisman C.J.N. \& Strik D.P.B.T.B. (2015) Plant microbial fuel cell applied in wetlands: Spatial, temporal and potential electricity generation of Spartina anglica salt marshes and Phragmites australis peat soils. Biomass \& Bioenergy 83: 543-550. https://doi.org/10.1016/j.biombioe.2015.11.006

Wetser K., Dieleman K., Buisman C. \& Strik D. (2017) Electricity from wetlands: Tubular plant microbial fuels with silicone gas-diffusion biocathodes. Applied Energy 185: 642-649. https://doi.org/10.1016/j.apenergy.2016.10.122

Yang J., Yu Q. \& Gong P. (2008) Quantifying air pollution removal by green roofs in Chicago. Atmospheric Environment 42 (31) 7266-7273. https://doi.org/10.1016/j.atmosenv.2008.07.003 